\title{
Partitioning of Above-ground Dry Matter in 'Lambert' Sweet Cherry Trees With or Without Fruit
}

\author{
Frank Kappel \\ Agriculture Canada, Research Station, Summerland, B.C. VOH 1Z0, Canada \\ Additional index words. Prunus avium, deblossom, photosynthetic efficiency, harvest index, leaf area
}

\begin{abstract}
The effect of fruit on shoot growth, leaf area, and on dry weight (DW) partitioning into leaves, fruit, trunk, and branch sections was investigated using 7-year-old 'Lambert' sweet cherry (Prunus avium L.) trees. Dormant trees were sampled in the spring, and fruiting and deblossomed trees were sampled and compared at fruit harvest and just before leaf fall. Fruiting reduced shoot growth, leaf area, and above-ground DW accumulation of the trees. The annual above-ground DW accumulated was $13.4 \mathrm{~kg}$ for fruiting trees and $16.0 \mathrm{~kg}$ for nonfruiting trees. The greatest proportion of above-ground DW was partitioned to wood, whereas the least was partitioned to fruit. Currentseason's growth (wood and leaves) appears to be a greater sink for photosynthates than is fruit because a greater proportion of above-ground DW was partitioned to current-season's growth than to fruit.
\end{abstract}

The photosynthetic characteristics and carbohydrate partitioning of sweet cherries recently has been reported (Keller and Loescher, 1989; Roper and Kennedy, 1986; Roper et al., 1988), but very little information exists concerning the effect of fruit on vegetative growth of sweet cherry. Looney (1989) reported an increase in vegetative growth of sweet cherry trees with a reduced fruit count. The effect of fruiting on vegetative growth of apple trees, however, has been studied extensively (Avery, 1969, 1970; Barlow, 1964; Chandler and Heinicke, 1926; Forshey and Marmo, 1985; Maggs, 1963), with the fruit exhibiting a strong effect on the vegetative growth of apple trees. Unlike apples, sweet cherry "trees have a short season from bloom to harvest (50 to 70 days, depending on the cultivar), so that information from apple may not be applicable to sweet cherries. The objective of this study was to determine the partitioning of the above-ground DW of sweet cherry trees with or without (deblossomed) fruit.

\section{Materials and Methods}

'Lambert' sweet cherry trees on Prunus avium seedling rootstock, planted in 1983, were used in the study. The trees were carrying their third crop of fruit in 1989. The trees were spaced $4.9 \mathrm{~m}$ between rows and $4.3 \mathrm{~m}$ within rows, trained to a central leader, and were provided normal care as recommended for orchards in the interior of British Columbia. A weed-free 1.5m-wide strip was maintained around the trees with the use of herbicides. The alley-ways were sodded and mowed about monthly during the growing season. Ten trees were chosen in the early spring, and before growth commenced, the trunk circumference was measured $20 \mathrm{~cm}$ above the bud union and converted to trunk cross-sectional area (TCSA). The trees were pruned, and treatments were randomly assigned to the trees. The treatments consisted of deblossoming four trees (NF) during bloom and allowing the remaining four trees to set a normal crop (FR); two trees were sampled at the beginning of the season. Trees were sampled while dormant ( 5 Apr.), in July at fruit harvest (4-5 July), and in October before leaf fall (2-3 Oct.).

Received for publication 12 July 1990. Contribution no. 762, Agriculture Canada Research Station, Summerland, B.C. The skilled technical assistance of M. Bouthillier is gratefully acknowledged. The cost of publishing this paper was defrayed in part by the payment of page charges. Under postal regulations, this paper therefore must be hereby marked advertisement solely to indicate this fact.
Sampling consisted of dividing the trees into current-season's growth (except the dormant sampling); 1-year, 2-year, and 3year branch sections, scaffold branches; and trunk. The leaves and fruit (when present) were removed and dried at $70 \mathrm{C}$ to constant weight. The shoot length of all current-season's growth was measured before being dried. Leaf area was estimated for the component parts of the tree by developing regression equations for leaf area and leaf dry weight on a subsample of leaves for each segment of the tree. The wood was then dried to constant weight.

The experiment was arranged as a completely randomized design, with two trees sampled while dormant and two trees sampled for each treatment at harvest and just before leaf fall. Since the initial TCSA varied from 78.5 to $143 \mathrm{~cm}^{2}$, the initial TCSA was used as a covariate to account for the differences in initial tree size. All reported means and standard errors are adjusted by the use of the covariate.

\section{Results}

At the time of fruit harvest in July, shoot length of FR trees was $75 \%$ of the shoot growth of NF trees, but by October, this was reduced to $60 \%$ (Table 1). The total DW of fruit accounted for only $7 \%$ of the total DW of the tree. The fruit for the October-sampled trees were harvested on the same dates as the July-sampled trees. The total DW of leaves accounted for $\approx 15 \%$ of the total DW of the tree. In July, the DW for leaves was $92 \%$ and $84 \%$ (FR and NF trees, respectively) of the DW of leaves at the October sampling. The DW of leaves of NF trees was greater than that of FR trees at both sampling dates. The total DW of wood includes all above-ground wood. There was no difference in DW of wood between the FR and NF trees at the July sampling. The DW of wood at the July sampling was $71 \%$ and $65 \%$ of the DW of wood at the October sampling for FR and NF trees, respectively. In October, the DW of wood for NF trees was $18 \%$ higher than for the FR trees.

There was no difference in the DW of wood of current-season's growth between FR and NF trees at the July sampling (Fig. 1). There appeared to be differences in the DW of wood for the 3rd-year branch sections and the scaffold branches, but these likely are not due to the deblossoming treatments. At the

Abbreviations: DW, dry weight; FR, fruiting trees; HI, harvest index; NF, nonfruiting trees; TCSA, trunk cross-sectional area. 
Table 1. Total shoot length and adjusted total dry weights of fruit, leaves, and wood for sweet cherry trees with or without fruit at three sampling dates.

\begin{tabular}{|c|c|c|c|c|c|c|}
\hline \multirow[b]{2}{*}{$\begin{array}{c}\text { Sampling } \\
\text { date }\end{array}$} & \multirow[b]{2}{*}{ Treatment } & \multirow{2}{*}{$\begin{array}{l}\text { Shoot } \\
\text { length } \\
\text { (m) }\end{array}$} & \multicolumn{4}{|c|}{ Dry wt } \\
\hline & & & $\begin{array}{l}\text { Fruity } \\
(\mathrm{kg})\end{array}$ & $\begin{array}{l}\text { Leaves } \\
(\mathrm{kg})\end{array}$ & $\begin{array}{l}\text { Wood } \\
(\mathrm{kg})\end{array}$ & $\begin{array}{l}\text { Total } \\
(\mathrm{kg})\end{array}$ \\
\hline April & Dormant & 0 & 0 & 0 & $14.3 \pm 1.4$ & $14.3 \pm 1.4$ \\
\hline \multirow[t]{2}{*}{ July } & FR & $67.0 \pm 8.2$ & $1.4 \pm 0.4$ & $3.3 \pm 0.1$ & $15.8 \pm 1.2$ & $20.5 \pm 1.3$ \\
\hline & NF & $89.1 \pm 7.8$ & 0 & $3.6 \pm 0.1$ & $16.8 \pm 1.2$ & $20.4 \pm 1.3$ \\
\hline \multirow[t]{2}{*}{ October } & FR & $80.8 \pm 7.7$ & $2.0 \pm 0.4$ & $3.6 \pm 0.1$ & $22.1 \pm 1.2$ & $27.7 \pm 1.3$ \\
\hline & $\mathrm{NF}$ & $129.2 \pm 7.9$ & 0 & $4.3 \pm 0.1$ & $26.0 \pm 1.2$ & $30.3 \pm 1.3$ \\
\hline
\end{tabular}

${ }^{2}$ Adjusted by use of initial trunk cross-sectional area as a covariate, mean \pm SE.

${ }^{y}$ Fruit for both sampling periods were harvested on 'the same dates, 4 and 5 July 1989.

October sampling, the DW of the wood of the current-season's growth of the FR trees was $\approx 50 \%$ of the NF trees. The DW of the wood of the current-season's growth accounted for $\approx 8 \%$ and $12 \%$ of the total DW of wood in October for FR and NF trees, respectively. In October, the DW of wood for 3rd-year branch sections and older portions of the tree accounted for $71 \%$ and $78 \%$ of the total DW of wood for NF and FR trees, respectively; these are lower proportions than in July (84\% and $81 \%$ for NF and FR trees, respectively). There was little difference in the total DW of leaves between FR and NF trees at the July sampling. In October, the DW of leaves on currentseason's growth for FR trees was $72 \%$ of that of the NF trees. About $45 \%$ to $68 \%$ of the total DW of leaves was on the currentseason's growth and a further $22 \%$ to $33 \%$ occurred on firstyear branch sections. The DW of leaves on current-season's growth in October accounted for $9 \%$ of the total DW of the tree. About $44 \%$ of the total DW of the fruit developed on firstyear branch sections followed by $30 \%$ and $24 \%$ on second- and third-year branch sections, respectively.

When the annual DW accumulated is examined (i.e., subtracting DW of dormant wood from the DW of the other sampling dates), fruit accounted for $\approx 16 \%$ of the annual DW increment of the FR trees (Table 2). Leaves accounted for $41 \%$ and 53\% (FR and NF trees, respectively) of the annual DW increment at the July sampling. At the October sampling, this dropped to $27 \%$ of the annual DW increment. Wood accounted for $43 \%$ and $47 \%$ (FR and NF trees, respectively) of the annual DW increment in July and 58\% and 75\% (FR and NF trees, respectively) in October. The leaves and wood of the currentseason's growth accounted for the greatest proportion of the annual DW increment followed by first-year branch sections. There was a shift in the partitioning of DW from leaves to wood from the July to the October sampling for both FR and NF trees. The total amount of DW partitioned to fruit was less than the amount partitioned to leaves on current-season's growth.

The total leaf area of FR trees was less than that of NF trees (Fig. 2). Current-season's growth had the highest leaf area, ranging from $13.7 \mathrm{~m}^{2}$ (July FR) to $32.7 \mathrm{~m}^{2}$ (October NF), 44\% to $66 \%$ of the total leaf area of the trees, respectively. The NF trees had a greater leaf area on current-season's growth than the FR trees on the same sampling dates. There was no difference in leaf area for the portions of the tree older than the currentseason's growth. Leaves on first-year branches accounted for $28 \%$ of the total leaf area of the tree.

\section{Discussion}

Sweet cherry trees with fruit accumulated less DW and had less total shoot growth and leaf area than deblossomed trees. Looney (1989) reported increased vegetative growth of sweet cherries when fruit count was reduced by blossom or fruit removal. Crop load also affected the growth of peach trees because vegetative growth decreased with increased number of fruit (Chalmers and van den Ende, 1975; Miller and Walsh, 1988; Proebsting, 1958). In apple trees, fruiting decreased DW accumulation (Avery, 1969, 1970; Chandler, 1934; Chandler and Heinicke, 1926; Maggs, 1963), total shoot length (Avery, 1969, 1970; Forshey and Marmo, 1985; Maggs, 1963), and total leaf area (Forshey and Marmo, 1985; Maggs, 1963).

At the fruit harvest sampling (70 days after full bloom), $70 \%$ to $80 \%$ of the total shoot growth was completed, $72 \%$ to $100 \%$ of total leaf area was present, and $65 \%$ to $70 \%$ of the wood DW was accumulated. The remaining growth or DW accumulation occurred over the subsequent 90 days. Roper et al. (1988) measured leaf photosynthesis of 'Bing' sweet cherry trees with or without fruit from early May to just after fruit harvest in early July. The photosynthetic rate increased dramatically during stage II of fruit development, then reached a plateau until harvest, followed by a reduction just after harvest. Unfortunately, the values from just after harvest to leaf fall were not reported. If photosynthetic rates did continue to decrease after harvest, there may be a relationship between the reduced photosynthetic rate and the reduced growth rate.

The current-season's growth is a larger sink for photosynthates than the fruit. Regardless of sampling date, the proportion of annual DW increment was greater in current-season's leaves and wood than in the fruit for all components of the tree. This relationship does not hold for peaches (Miller and Walsh, 1988) or apple (Forshey et al., 1983), where the fruit are large sinks and accumulate more DW than shoots. Roper et al. (1988) reported that the photosynthetic rate of sweet cherry leaves was unaffected by fruiting. They suggested that photosynthetic rates were not affected by sink strength. The data from this study suggest that fruit may not be the predominant sink for photosynthates in sweet cherry trees and may, in part, explain the lack of difference in photosynthetic rate between fruiting and nonfruiting trees.

Avery $(1969,1970)$ reported that the greatest reduction in DW increment occurred in the root system. The DW accumulation in the root system was not estimated in this study. Roper et al. (1988) suggested that root carbohydrate reserves may not be important to crop development. They may play a role, however, in the vegetative growth of the scion. Dolph and Proebsting (1989) reported that restricting root growth by confining roots of sweet cherries in reduced soil volumes reduced the vegetative growth of the scion.

The ratio of annual DW produced to leaf area is a measure of the photosynthetic efficiency of the foliage (Avery, 1969). Leaves of FR trees were more efficient than leaves of NF trees. 
Table 2. Proportion of annual DW increment ${ }^{2}$ partitioned to wood, leaves, and fruit in the component parts of trees with or without fruit sampled in July and October.

\begin{tabular}{|c|c|c|c|c|c|c|c|}
\hline $\begin{array}{c}\text { Sampling } \\
\text { date }\end{array}$ & Fruit & $\begin{array}{c}\text { Part } \\
\text { of tree } \\
\end{array}$ & $\begin{array}{c}\text { Current- } \\
\text { season's } \\
\text { growth }\end{array}$ & $\begin{array}{l}1 \text {-year } \\
\text { branch } \\
\text { section }\end{array}$ & $\begin{array}{c}\text { 2- and 3-year } \\
\text { branch } \\
\text { sections }\end{array}$ & $\begin{array}{c}\text { Scaffold } \\
\text { and trunk }\end{array}$ & Totaly \\
\hline & . & & & & (Percent) & & \\
\hline \multirow[t]{8}{*}{ July } & \multirow[t]{4}{*}{ Present } & Wood ${ }^{\mathbf{x}}$ & 8.6 & 4.9 & 16.0 & 13.6 & 43.1 \\
\hline & & Leaves & 18.5 & 13.5 & 7.4 & 1.1 & 40.5 \\
\hline & & Fruit & 0 & 6.2 & 9.9 & 0.7 & 16.8 \\
\hline & & Total & 27.1 & 24.6 & 33.3 & 15.4 & \\
\hline & \multirow[t]{4}{*}{ Absent } & Wood & 10.3 & 7.4 & 5.9 & 23.6 & 47.2 \\
\hline & & Leaves & 27.9 & 16.2 & 7.3 & 1.3 & 52.7 \\
\hline & & Fruit & 0 & 0 & 0 & 0 & 0 \\
\hline & & Total & 38.2 & 23.6 & 13.2 & 24.9 & \\
\hline \multirow[t]{8}{*}{ October } & \multirow[t]{4}{*}{ Present } & Wood & 12.7 & 8.2 & 7.4 & 29.8 & 58.1 \\
\hline & & Leaves & 15.7 & 7.5 & 2.9 & 0.4 & 26.5 \\
\hline & & Fruit & 0 & 7.5 & . 7.4 & 0.1 & 15.0 \\
\hline & & Total & 28.4 & 23.2 & 17.7 & 30.3 & \\
\hline & \multirow[t]{4}{*}{ Absent } & Wood & 19.4 & 10.0 & 18.8 & 25.0 & 73.2 \\
\hline & & Leaves & 18.6 & 5.6 & 2.5 & 0.2 & 26.9 \\
\hline & & Fruit & 0 & 0 & 0 & 0 & 0 \\
\hline & & Total & 38.0 & 15.6 & 21.3 & 25.2 & \\
\hline
\end{tabular}

${ }^{2}$ Total annual DW increment was: fruit present: July, $6.2 \mathrm{~kg}$; October, $13.4 \mathrm{~kg}$; fruit absent: July, $6.1 \mathrm{~kg}$; October, $16.0 \mathrm{~kg}$.

'Totals may not equal 100 '\% because of rounding.

${ }^{x}$ Adjusted dry weight of dormant wood (sampled in April) was 0.6, 1.5, 1.9, 4.0, and 6.3

$\mathrm{kg}$ for first-, 2nd-, and 3rd-year branches, scaffold, and trunk, respectively.

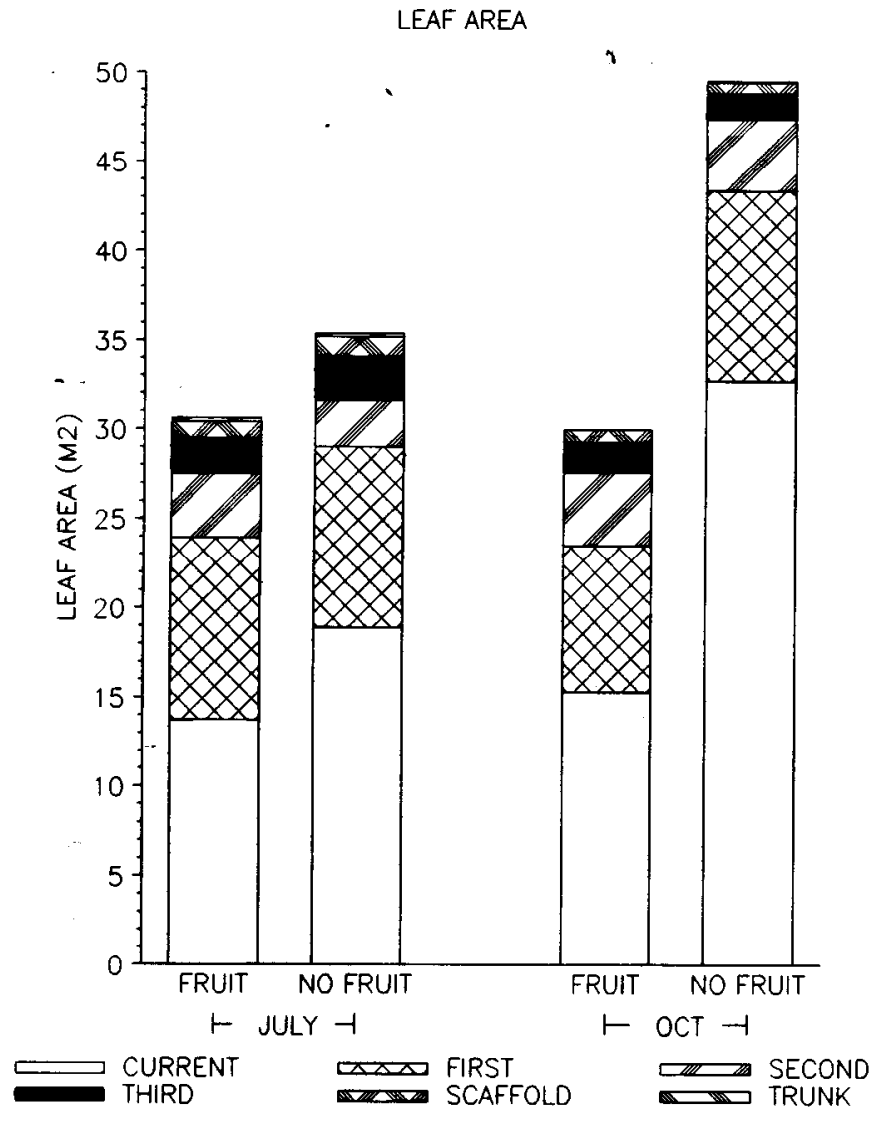

Fig. 2. Adjusted leaf areas associated with various components of sweet cherry trees with or without fruit at two sampling dates. The leaf areas were adjusted by use of initial TCSA as a covariate.

ing, the cherry trees still had not completely filled their allotted space.
This study demonstrates that fruiting reduces the vegetative growth of the scion of sweet cherries, but the reduction is not as great as with apples or peaches. It also indicates that the current-season's growth (wood and leaves) is a larger sink for photosynthates than the total fruit crop of the tree. These relationships need to be understood for sweet cherries before management practices can redeveloped to manipulate both fruiting and vegetative growth.

\section{Literature Cited}

Avery, D.J. 1969. Comparisons of fruiting and deblossomed maiden apple trees, and of non-fruiting trees on a dwarfing and invigorating rootstock. New Phytol. 68:323-336.

Avery, D.J. 1970. Effects of fruiting on the growth of apple trees on four rootstock varieties. New Phytol. 69:19-30.

Barlow, H.B.W. 1964. An interim report on a long-term experiment to assess the effect of cropping on apple tree growth. Annu. Rpt. East Mailing Res. Sta., 1963. p. 84-93.

Chalmers, D.J. and B. van den Ende. 1975. Productivity of peach trees: Factors affecting dry-weight distribution during tree growth. Ann. Bet. 39:423-432.

Chandler, W.H. 1934. The dry-matter residue of trees and their products in proportion to leaf area. Proc. Amer. Soc. Hort. Sci. 31:3956.

Chandler, W.H. and A.J. Heinicke. 1926. The effect of fruiting on the growth of Oldenburg apple trees. Proc. Amer. Soc. Hort. Sci. 23:36-46.

Dolph, C.A. and E.L. Proebsting. 1989. Root confinement affects growth and physiology of sweet cherry and apple. ASHS 1989 Annu. Mtg., Tulsa, Okla., Prog. \& Abstr. p. 99.

Forshey, C.G. and C.A. Marmo. 1985. Pruning and deblossoming effects on shoot growth and leaf area of 'McIntosh' apple trees. J. Amer. Soc. Hort. Sci. 110:128-132.

Forshey, C. G., R.W. Weires, B.H. Stanley, and R.C. Seem. 1983. Dry weight partitioning of 'McIntosh' apple trees. J. Amer. Soc. Hort. Sci. 108:149-154.

Keller, J.D. and W.H. L.oescher. 1989. Nonstructural carbohydrate 
partitioning in perennial parts of sweet cherry. J. Amer. Soc. Hort. Sci. 114:969-975.

Looney, N.E. 1989. Effects of crop reduction, gibberellin sprays and summer pruning on vegetative growth, yield and quality of sweet cherries, p. 39-50. In: C.J. Wright (cd.). Manipulation of fruiting. Butterworths, London.

Maggs, D.H. 1963. The reduction of growth of apple trees brought about by fruiting. J. Hort. Sci. 38:119-128.

Miller, A.N. and C.S. Walsh. 1988. Growth and seasonal partitioning of dry matter in eight-year-old 'Loring' peach trees. J. Amer. Soc. Hort. Sci. 113:309-314.
Proctor, J. T. A., R.L. Watson, and J.J. Landsberg. 1976. The carbon budget of a young apple tree. J. Amer. Soc. Hort. Sci. 101:579-582. Proebsting, E.L. 1958. A quantitative evaluation of the effect of fruiting on growth of Elberta peach trees. Proc. Amer. Soc. Hort. Sci. 71:103-109.

Roper, T.R. and R.A. Kennedy. 1986. Photosynthetic characteristics during leaf development in 'Bing' sweet cherry. J. Amer. Soc. Hort. Sci. 111:938-941.

Roper, T. R., J.D. Keller, W.H. Loescher, and C.R. Rem. 1988. Photosynthesis and carbohydrate partitioning in sweet cherry: Fruiting effects. Physiol. Plant. 72:42-47. 